\title{
Indentifikasi Pasar, Segmen Dan Target Pasar Sasaran Bisnis Asuransi
}

\author{
Habib Bayhaqi ${ }^{1}$, Nuri Aslami ${ }^{2}$ \\ ${ }^{1,2}$ Universitas Islam Negeri Sumatra Utara \\ habib.bayhaqie17072001@gmail.com
}

\begin{abstract}
To achieve the still-small target of insurance participants in Indonesia, as well as the potential benefits of market and company segmentation, empirical research into consumer needs and desires, as well as a management system capable of adapting business processes to these needs and desires, are required. Consumers in target sharia insurance participants make purchases based on the advantages offered or the potential of items and services to assist them in solving a specific problem. Companies might provide a wide range of items and services, but customers only purchase advantages or solutions to issues that the products and services in question provide.
\end{abstract}

Keyword: Market Identification, Strategy, Definition, Insurance

\begin{abstract}
Abstrak
Untuk mencapai target peserta asuransi yang masih kecil di Indonesia, serta potensi keuntungan dari segmentasi pasar dan perusahaan, riset empiris terhadap kebutuhan dan keinginan konsumen, serta sistem manajemen yang mampu mengadaptasi proses bisnis dengan kebutuhan dan keinginan tersebut, diperlukan. Konsumen dalam target peserta asuransi syariah melakukan pembelian berdasarkan keunggulan yang ditawarkan atau potensi barang dan jasa untuk membantu mereka dalam memecahkan suatu masalah tertentu. Perusahaan mungkin menyediakan berbagai macam item dan layanan, tetapi pelanggan hanya membeli keuntungan atau solusi untuk masalah yang disediakan oleh produk dan layanan tersebut.
\end{abstract}

Kata Kunci: Identifikasi Pasar, Strategi, Definisi, Asuransi

\section{PENDAHULUAN}

Ada tiga taktik pemasaran, menurut Kotler: Dengan membagi pasar menjadi segmen-segmen, perusahaan dapat lebih fokus pada pengalokasian sumber daya. Segmentasi pasar (segmenting) adalah proses mengevaluasi daya tarik setiap segmen dan kemudian memilih satu. atau lebih karakteristik yang akan dilayani, serta pertanyaan tentang bagaimana memilih, memilih, dan menjangkau pasar. Diferensiasi adalah tindakan merancang serangkaian perbedaan yang berarti dalam penawaran perusahaan.

Langkah pertama adalah membagi pasar menjadi segmen-segmen. Karena pasar tidak seragam, produk pemasaran harus disesuaikan untuk kelompok klien yang berbeda, sesuai dengan premis inti segmentasi pasar. Jika Anda seorang pebisnis, Anda harus memahami di mana, bagaimana, dan kepada siapa Anda memasarkan produk atau layanan Anda. Segmentasi pasar adalah salah satu hal yang dapat membantu Anda 
mengembangkan dan mengembangkan bisnis Anda. Tujuan dari kategorisasi pasar dalam prosedur pemasaran ini adalah untuk meningkatkan penjualan dan profitabilitas produk. Jika perusahaan dapat melakukan segmentasi yang baik dan kemudian memilih salah satu kategori terbaik untuk menjadi target pasar, segmentasi pasar akan menguntungkan. Pemasaran bukan hanya tentang menjual produk atau jasa; ini juga tentang memperhatikan segmen pasar yang ada. Jika pemasaran hanya terfokus untuk menarik sejumlah besar pelanggan tanpa memperhatikan segmen pasar, pemasaran mungkin tidak berjalan dengan lancar sama sekali, bahkan jika hanya beberapa barang yang laku di pasar. Setelah itu, pemasaran dapat terhenti kapan saja.

Artikel ini bertujuan memberikan paparan mengenai Identifikasi pasar, Segmen dan Target pasar sasarab bisnis dalam asuransi.

\section{PEMBAHASAN}

\section{Pemasaran Efektif}

Kriteria yang harus dipenuhi oleh segmen pasar agar proses segmentasi pasar menjadi efektif dan menguntungkan bagi perusahaan, antara lain:

a. Terukur, dalam arti bahwa ukuran segmen pasar, serta luasnya dan daya belinya, semuanya dapat diukur. sebuah. Dihargai dengan masuk akal

b. (Reachable), menyiratkan bahwa segmen pasar dapat diakses dan dilayani secara efisien.

c. Sangat luas (substansial) untuk menguntungkan jika dipasok.

d. Dapat dieksekusi (Actionable), memastikan keberhasilan setiap inisiatif yang dirancang untuk merekrut dan melayani ceruk pasar tersebut.

e. Dapat dikenali (Differentiable), yaitu segmen dapat dikenali dari ciri-cirinya dan merespons penawaran program pemasaran secara berbeda.

\section{Strategi Pemasaran}

Menurut Benjamin Molan, strategi adalah program yang luas untuk menetapkan dan mencapai tujuan organisasi, serta reaksi jangka panjang organisasi terhadap lingkungannya. Strategi pemasaran, menurut Philip Kotler, adalah sikap pemasaran yang akan digunakan untuk mencapai tujuan pemasaran. Taktik khusus untuk pasar sasaran, penentuan posisi, bauran pemasaran, dan pengeluaran pemasaran semuanya termasuk dalam strategi pemasaran. Onong Uchayana Effendy mendefinisikan strategi sebagai "perencanaan dan administrasi untuk mencapai tujuan tersebut." Strategi bukan hanya rencana jalan yang menunjukkan ke mana Anda harus pergi; itu juga harus menunjukkan kepada Anda bagaimana metode operasional bekerja.

Tujuan jangka panjang perusahaan, serta penggunaan dan alokasi semua sumber daya penting untuk mencapai tujuan ini, disebut sebagai strategi. Untuk bersaing dalam iklim bisnis yang kompetitif, perusahaan harus memiliki rencana untuk mendapatkan keunggulan kompetitif. Karena ada pesaing yang bisa mengungguli produk suatu perusahaan. Koordinasi tim kerja, memiliki tema, menemukan variabel pendukung yang sesuai dengan prinsip menerapkan ide secara logis, efisien dalam pendanaan, dan memiliki metode untuk mencapai tujuan dengan sukses adalah bagian dari strategi yang kuat. 
Menurut Tjiptono "Strategi pemasaran adalah alat fundamental yang direncanakan untuk mencapai perusahaan dengan mengembangkan keunggulan bersaing yang berkesinambungan melalui pasar yang dimasuki dan program pemasaran yang digunakan untuk melayani pasar sasaran tersebut.". Intinya adalah mengidentifikasi dan memenuhi kebutuhan manusia dan sosial. Salah satu definisi yang baik dan singkat dari pemasaran adalah memenuhi kebutuhan dengan cara yang menguntungkan.

Ini adalah proses sosiokultural di mana orang dan kelompok mendapatkan apa yang mereka inginkan dengan menciptakan, menawarkan, dan secara bebas memperdagangkan barang dan jasa yang berharga dengan orang lain. Namun, ungkapan esensial dalam konsep pemasaran syariah adalah tidak boleh ada barang yang melanggar akad dan prinsip muamalah dalam Islam di seluruh proses, termasuk proses produksi, pasokan, dan perubahan nilai. Semua jenis transaksi ekonomi diperbolehkan menurut hukum Islam selama hal ini dapat dijamin dan tidak terjadi pelanggaran dari prinsip-prinsip muamalah. Oleh karena itu, Allah menyarankan kita untuk menghindari praktik buruk dalam bisnis, terutama dalam proses menghasilkan, menawarkan, dan mengubah nilai pemasaran. Lima konsep strategi sebagai berikut :

a. Segmentasi pasar. Ada kemungkinan bahwa bisnis tidak akan dapat memenuhi keinginan setiap pelanggan. Akibatnya, bisnis harus membagi pasar yang beragam menjadi segmen pasar yang homogen

b. Posisi di pasar. Karena korporasi mungkin tidak dapat menguasai seluruh pasar, ia harus memilih sektor pasar yang akan menciptakan penjualan dan keuntungan tertinggi. Sektor pasar ini memiliki empat karakteristik yang berbeda:

- Memiliki permintaan yang belum terpenuhi yang dapat dipenuhi oleh perusahaan yang memilih sektor tersebut.

- Cukup besar.

- Memiliki kemampuan untuk berkembang.

- Tidak memiliki atau dapat dipenuhi oleh perusahaan pesaing.

c. Strategi bauran pemasaran adalah seperangkat variabel yang mungkin digunakan perusahaan untuk mempengaruhi tanggapan pelanggan (produk, harga, lokasi, promosi, partisipasi, proses, dan bukti fisik orang).

d. Metodologi Waktu Penting untuk membuat pilihan yang tepat dalam hal pemasaran. Terlepas dari kenyataan bahwa tidak ada waktu untuk membuat tujuan atau mengembangkan rencana pemasaran, organisasi dapat memulai operasi pemasaran sekali saja. Korporasi harus terlebih dahulu melakukan persiapan baik di bidang manufaktur maupun pemasaran, kemudian memilih momen terbaik untuk meluncurkan barang dan jasa ke pasar.

e. Posisi bersaing, Kepuasan konsumen dengan upaya pemasaran yang dilakukan oleh perusahaan untuk produknya merupakan penentu utama dari strategi pemasaran yang sukses. Berdasarkan premis ini, masuk akal untuk menyimpulkan bahwa salah satu maksud dan tujuan pemasaran produk adalah untuk memuaskan pelanggan. Setiap bisnis dalam industri tertentu memiliki strategi bersaing. Tantangan utama yang harus diatasi untuk melaksanakan perencanaan yang efisien adalah upaya untuk mengidentifikasi dan meneliti saingan. Perusahaan harus membandingkan barang, harga, metode distribusi, dan promosi mereka dengan barang pesaing langsung mereka secara teratur. Akibatnya, perusahaan dapat dengan jelas melihat area kelebihan dan kekurangan calon pesaing. Korporasi dapat meluncurkan serangan yang lebih 
agresif terhadap para pesaingnya sementara juga membangun pertahanan yang lebih baik terhadap serangan gencar.

\section{Pasar Asuransi}

Pasar digambarkan sebagai lokasi di mana permintaan dan penawaran barang dan jasa ditetapkan melalui penetapan harga dan jumlah yang dibutuhkan. Kami dapat dibandingkan dengan pusat layanan untuk semua jenis barang yang berhubungan dengan asuransi di industri asuransi. Layanan tersebut akan disajikan dalam bentuk statistik yang mengungkapkan seberapa besar pangsa pasar yang dimiliki produk atau layanan asuransi.

\section{Struktur Pasar Asuransi}

Seperti pasar yang lain, pasar asuransi terdiri dari, Penjual : perusahaan asuransi dan underwriting, Pembeli : publik umum, industri dan dagang, Perantara asuransi : agen dan konsultan. Masyarakat umum adalah pembeli rencana asuransi pribadi. Seseorang mungkin memiliki berbagai kebijakan pribadi, seperti asuransi mobil pribadi, asuransi isi rumah dan bangunan, asuransi jiwa, dan asuransi kesehatan, tergantung pada posisinya. Asuransi pribadi, di sisi lain, tidak mendominasi industri asuransi pada umumnya. Banyak bisnis asuransi mengkhususkan diri dalam asuransi komersial dan industri yang memakan waktu, di mana pembayaran premi satu pelanggan mungkin mencapai jutaan rupiah setiap tahun.

\section{Strategi Pemasaran Syariah untuk Memenangkan Market Share (Pangsa Pasar)}

Persentase seluruh pasar untuk kategori produk atau jasa yang dipilih dan dikendalikan oleh satu atau lebih barang atau jasa tertentu yang dipasok oleh perusahaan dalam kategori yang sama disebut sebagai pangsa pasar. Dan setiap perusahaan memiliki pendekatan unik untuk menangkap pangsa pasar tertentu. Salah satunya adalah dengan melaksanakan rencana yang dipilih, dalam hal ini korporasi dapat menggunakan metode pemasaran seperti:

1. Diferensiasi adalah pembeda, atau cara untuk membedakan diri Anda dari produk atau bisnis lain. Dibandingkan dengan pesaing lainnya, keunggulan diferensiasi adalah salah satu kualitas khas bisnis yang menginspirasi konsumen sasaran untuk menjadi klien setia. Mengintegrasikan materi (konten), konteks (konteks), dan infrastruktur (infrastruktur) perusahaan sehingga dapat menjadi nilai tambah yang dapat diberikan perusahaan kepada klien adalah salah satu metode untuk membuat perbedaan.

2. Bauran pemasaran perusahaan adalah pendekatan yang digunakan untuk mencapai tujuan pemasarannya di pasar sasaran. Penawaran terdiri dari produk dan harga, sedangkan akses terdiri dari lokasi dan pemasaran. Akibatnya, bauran pemasaran yang dimaksud adalah bagaimana menggabungkan penawaran dari perusahaan yang memiliki akses ke pasar. Efektivitas inisiatif pemasaran perusahaan tergantung pada proses integrasi ini. Untuk syariah, sesuai dengan prinsip syariah, untuk penawaran (offers), barang, dan penetapan harga berdasarkan cita-cita kejujuran dan keadilan. Kualitas produk yang diberikan harus sesuai dengan apa yang ditawarkan

3. Penjualan Untuk menjaga loyalitas pelanggan, korporasi tidak hanya menambahkan fitur pada produk dan layanan yang dijualnya, tetapi juga keunggulan dan bahkan solusi untuk produk dan layanan tersebut. Tidak dapat diterima, misalnya, untuk 
menyediakan produk dengan harga rendah untuk mempengaruhi pembeli sekaligus menurunkan kualitasnya. Konsumen pada awalnya mungkin tertarik. Mereka akan, bagaimanapun, keluar dari perusahaan palsu setelah mereka menyadari bahwa mereka telah ditipu.

\section{Defenisi Segmen Pasar}

Wendell R. Smith mencetuskan gagasan segmentasi pasar dalam makalahnya yang terkenal "Diferensiasi Produk dan Segmentasi Pasar sebagai Strategi Pemasaran Alternatif" yang diterbitkan dalam jurnal Pemasaran pada tahun 1956. Karena pasar tidak seragam, solusi pemasaran harus disesuaikan untuk kelompok klien yang berbeda, menurut dengan ide utama segmentasi pasar. Segmentasi pasar adalah proses memecah pasar menjadi kelompok pelanggan yang berbeda yang memiliki keinginan, ciri, atau kebiasaan yang berbeda (heterogen) dan mungkin memerlukan barang atau bauran pemasaran yang berbeda.

Segmentasi pasar adalah gagasan kunci yang mendukung strategi pemasaran perusahaan dan alokasi sumber daya yang diperlukan untuk melaksanakan inisiatif pemasaran. Berikut ini adalah beberapa definisi segmentasi pasar yang diambil dari berbagai sumber teoritis:

a. Segmentasi pasar merupakan upaya menata pasar yang beragam menjadi pasar yang bersifat homogen (Gitosudarno, 2008).

b. Segmentasi pasar adalah proses memecah pasar ke dalam kategori pelanggan yang berbeda yang mungkin memerlukan pemasaran atau penawaran produk yang berbeda (Amstrong, 1997:227).

c. Segmentasi pasar, menurut Hermawan Kertajaya, merupakan sarana untuk melihat pasar secara kreatif untuk mengidentifikasi/memanfaatkan kemungkinan pasar. Dalam bisnis dan pemasaran, segmentasi pasar sangat penting.

Memahami segmentasi pasar sebagai strategi perusahaan didasarkan pada perbedaan minat dan permintaan pelanggan, bukan hanya membedakan item atau memproduksi produk baru (diversifikasi produk).

Aspek yang paling berharga dari segmentasi pasar ini adalah belajar bagaimana mengenali dan memahami karakteristik setiap kategori, serta menemukan strategi yang efisien untuk melayani masing-masing kategori. Jadi segmentasi pasar adalah proses keseluruhan di mana bisnis harus memperhatikan pembelian dari masing-masing sektor; paling tidak, jika pembelian unit dibagi ke dalam berbagai kelompok, perusahaan akan lebih hemat biaya. Semua ini tidak dapat dipisahkan dari upaya memaksimalkan keuntungan.

\section{Kriteria Sekmentasi Pasar yang Efektif}

Karena terdapat berbagai pelanggan dengan kebutuhan dan keinginan yang bervariasi dalam suatu pasar, maka diperlukan segmentasi pasar. Akibatnya, segmentasi pasar di perusahaan dibuat dengan tujuan untuk mengidentifikasi prospek segmen pasar perusahaan. Akibatnya, organisasi akan dapat menentukan sektor pasar mana yang paling efektif. Berikut adalah contoh karakterisasi atau kriteria segmen pasar:

1. Penentuan segmen yang diakui yang sebenarnya berbeda dari yang lain.

2. Pengukuran adalah segmen-segmen yang harus dilakukan dalam hal variasi karakteristik dan karakteristik rumah tangga, atau karakteristik lainnya. 
3. Tersedia saluran diseminasi. Ukuran, daya beli, dan profil adalah semua faktor yang perlu dipertimbangkan.

4. Konsisten (tidak terlalu cepat berubah).

5. Menanggapi bauran pemasaran dengan cara yang unik.

Mengikuti perbedaan antara berbagai kategori pasar, langkah selanjutnya adalah memilih salah satu segmen pasar tersebut. Pilihan target pasar mungkin dibuat dalam satu segmen atau banyak segmen dalam skenario ini. Karakteristik berikut harus dipertimbangkan saat memilih target pasar yang terbaik:

$>$ Responsif adalah kata yang terlintas di benak saya ketika memikirkan tentang daya tanggap Produk atau kampanye pemasaran yang dirancang harus relevan dengan pasar sasaran. Proses ini harus dimulai dengan analisis segmentasi pasar yang menyeluruh, karena tanpa analisis tersebut, ada risiko yang signifikan.

$>$ Kemungkinan penjualan Potensi penjualan harus cukup. Semakin tinggi skornya, semakin besar tujuannya. Jumlahnya diatur tidak hanya oleh populasi, tetapi juga oleh daya beli pasar dan keinginan untuk memperoleh barang.

$>$ Cukup ekspansi Pasar tidak dapat merespon dengan cepat. Pasar akan berkembang perlahan pada awalnya, kemudian dengan cepat saat mendekati kedewasaan.

\section{Pola Pemilihan Target Pasar Asuransi}

Proses menganalisis daya tarik setiap segmen dan kemudian memilih satu atau lebih kualitas untuk ditayangkan dikenal sebagai penargetan. Penargetan adalah proses memilih, memilih, dan menjangkau pasar tertentu. Tahapan analisis segmentasi selanjutnya adalah membidik atau memilih pasar sasaran. Pasar sasaran (target market) adalah produk dari penargetan, yaitu satu atau lebih kelompok pasar yang akan menjadi fokus upaya pemasaran. Karena pemasar harus memilih, maka penargetan juga disebut sebagai memetik. Perusahaan harus memilih klien yang dapat dijangkau dan dilayani dengan sukses dan efisien, yang ditunjukkan dalam proses penargetan.

Setelah organisasi selesai melakukan segmentasi pasar, tahap selanjutnya adalah menentukan pasar, kemudian memilih aktivitas setiap segmen, dan terakhir, melayani satu atau lebih segmen pasar. Tentukan pasar sasaran dengan terlebih dahulu menentukan ukuran dan daya tarik segmen, kemudian memilih segmen sasaran yang dituju. Ada beberapa metode untuk menentukan target pasar, antara lain:

1. Spesialisasi memungkinkan perusahaan untuk memilih dari berbagai sektor pasar yang menarik berdasarkan tujuan dan sumber dayanya.

2. Spesialisasi pasar dari bisnis yang mementingkan diri sendiri untuk memenuhi beragam keinginan kelompok konsumen tertentu.

3. Keahlian produk perusahaan yang mencari sendiri adalah dalam menciptakan produk yang akan dipasarkan ke berbagai sektor pasar.

4. Layanan penuh (cakupan pasar lengkap): perusahaan berusaha menyediakan semua barang untuk semua kelompok konsumen. Hanya organisasi besar yang mampu menerapkan pendekatan ini, karena memerlukan berbagai sumber daya.

\section{Evaluasi Pemilihan Target Pasar Asuransi}

Segmen pasar dapat dievaluasi menggunakan sembilan kriteria yang dapat dibagi menjadi dua kategori: Pertama, pertimbangkan ukuran segmen dan prospek pengembangan. Sementara pasar yang besar dan meningkat mungkin tampak lebih 
menarik, ukuran dan potensi segmen pertumbuhan yang kompetitif cocok dengan sumber daya dan keterampilan organisasi perusahaan mana pun. Sumber daya organisasi, seperti ketersediaan keahlian, keuangan, dan jumlah outlet distribusi, terkadang dapat menjadi hambatan bagi upaya perusahaan untuk mengiklankan tingkat pertumbuhan yang tinggi. Kedua, fitur segmen struktural seperti persaingan, perlindungan saturasi segmen, dan risiko lingkungan. Perusahaan harus meningkatkan intensitas dan dinamika persaingan dalam kaitannya dengan hambatan masuk, hambatan keluar, ancaman pendatang baru, tekanan dari produk atau jasa pengganti, daya tawar penawaran, dan daya tawar pelanggan.

Selain itu, ada bahaya identifikasi, seperti kemungkinan inovasi dan kreasi rasa perusahaan tidak dilindungi oleh hak cipta dan paten, serta risiko perubahan lingkungan. Sebuah perusahaan harus mempertimbangkan dua kriteria saat menganalisis segmen pasar yang berbeda: daya tarik keseluruhan segmen dan tujuan serta sumber daya organisasi. Perusahaan harus mempertimbangkan apakah sektor yang memungkinkan memiliki kualitas seperti ukuran, pertumbuhan, profitabilitas, skala ekonomi, risiko rendah, dan sebagainya yang membuatnya menarik secara umum. Organisasi kemudian harus memeriksa apakah berinvestasi di segmen itu masuk akal mengingat tujuan dan sumber dayanya. Beberapa kategori yang menarik dapat dikecualikan jika tidak terkait dengan tujuan jangka panjang perusahaan.

Pada kenyataannya, jika segmen tersebut sesuai dengan keterampilan dan sumber daya yang tersedia, pasar di sektor tersebut dapat dimenangkan. Jika perusahaan tidak memiliki satu atau dua kompetensi yang dibutuhkan dan tidak dapat memperolehnya, bagian tersebut harus dihapus. Bahkan jika sebuah perusahaan memiliki keterampilan yang diperlukan, ia harus membangun keuntungan yang lebih baik.

\section{KESIMPULAN}

Dari pemaparan yang telah penulis jelaskan, dapat disimpulkan bahwa saluran pemasaran adalah Kriteria yang harus dipenuhi segmen pasar agar proses segmentasi pasar dapat dijalankan dengan efektif : Measurable, Accessible, Substantial, Actionable, Differentiable.

Pasar digambarkan sebagai lokasi di mana permintaan dan penawaran barang dan jasa ditetapkan melalui penetapan harga dan jumlah yang dibutuhkan. Kami dapat dibandingkan dengan pusat layanan untuk semua jenis barang yang berhubungan dengan asuransi di industri asuransi. Layanan tersebut akan disajikan dalam bentuk statistik yang mengungkapkan seberapa besar pangsa pasar yang dimiliki produk atau layanan asuransi. Segmentasi pasar adalah proses yang luas di mana bisnis harus memperhatikan pembelian dari setiap bagian; Paling tidak, perusahaan akan lebih hemat biaya jika pembelian unit dibagi ke dalam kelompok yang berbeda.

\section{DAFTAR PUSTAKA}

Irawan, Swasta Basu. 2002. Manajemen Pemasaran Modern. Yogyakarta: Liberty

Molan, Benyamin. 2020. Glosarium Prentice Hall: Manajemen \& Pemasaran. Jakarta:

Prenhallindo 
Uchyana, Onong. 1992. Ilmu Komunikasi Teori dan Praktek. Bandung: PT. Remaja Rosdakarya

Rahmawati. 2016. Manajemen Pemasaran. Samarinda: Mulawarman University Press.

Ikatan Bankir Indonesia (IBI). 2014. Memahami Bisnis Bank. Jakarta: Gramedia.

Sumarwan, U., \& Tjipono, F. 2019. Strategi Pemasaran Dalam Perspektif Perilaku Konsumen. Bogor: PT. Penerbit IPB Press. 